\title{
Animal-sediment interactions: the effect of ingestion and excretion by worms on mineralogy
}

\author{
S. J. Needham ${ }^{1}$, R. H. Worden ${ }^{1}$, and D. McIlroy ${ }^{2}$ \\ ${ }^{1}$ Dept. of Earth and Ocean Sciences, University of Liverpool, 4 Brownlow St, Liverpool L69 3GP, UK \\ ${ }^{2}$ Department of Earth Sciences, Memorial University, St. John's, Newfoundland, A1B 3X5, Canada
}

Received: 23 August 2004 - Published in Biogeosciences Discussions: 7 September 2004

Revised: 15 November 2004 - Accepted: 24 November 2004 - Published: 25 November 2004

\begin{abstract}
By controlled experiments that simulate marine depositional environments, it is shown that accelerated weathering and clay mineral authigenesis occur during the combined process of ingestion, digestion and excretion of fine-grained sediment by two species of annelid worms. Previously characterized synthetic mud was created using finely ground, low-grade metamorphic slate (temperature approximately $300^{\circ} \mathrm{C}$ ) containing highly crystalline chlorite and muscovite. This was added to experiment and control tanks along with clean, wind-blown sand. Faecal casts were collected at regular intervals from the experimental tanks and, less frequently, from the control tanks. Over a period of many months the synthetic mud (slate) proved to be unchanged in the control tanks, but was significantly different in faecal casts from the experimental tanks that contained the worms Arenicola marina and Lumbricus terrestris. Chlorite was preferentially destroyed during digestion in the gut of $A$. marina. Both chlorite and muscovite underwent XRD peak broadening with a skew developing towards higher lattice spacing, characteristic of smectite formation. A neoformed Fe-Mg-rich clay mineral (possibly berthierine) and as-yet undefined clay minerals with very high $d$-spacing were detected in both A. marina and L. terrestris cast samples. We postulate that a combination of the low $\mathrm{pH}$ and bacteria-rich microenvironment in the guts of annelid worms may radically accelerate mineral dissolution and clay mineral precipitation processes during digestion. These results show that macrobiotic activity significantly accelerates weathering and mineral degradation as well as mineral authigenesis. The combined processes of sediment ingestion and digestion thus lead to early diagenetic growth of clay minerals in clastic sediments.
\end{abstract}

Correspondence to: S. J. Needham

(sneedham@liv.ac.uk)

\section{Introduction}

Chemical weathering of silicate minerals and the growth of new authigenic minerals was, until fairly recently, only considered in terms of inorganic processes. Unstable silicate minerals are conventionally thought to undergo processes such as oxidation/reduction, dissolution and hydrolysis to produce a degraded primary mineral and neoformed clay minerals (Chamley, 1989). These processes are considered to be strongly influenced by the presence of weak inorganic acids such as carbonic acid in rainwater (Drever, 1988). Whilst the numerous complexities and parameters of the weathering environment are hard to simulate, it is well documented that these processes take a geologically significant period of time. Sverdrup and Warfvinge (1995) gave a value of $0.003 \mathrm{keq} \cdot \mathrm{ha}^{-1} \mathrm{yr}^{-1}$ to describe the rate of K-feldspar undergoing chemical weathering. Using a case study in the Coweeta Basin North Carolina, Drever and Clow (1995) deduced a biotite weathering rate of $1.2 \times 10^{-13} \mathrm{~mol}^{-2} \mathrm{~m}^{-1}$. Field and laboratory weathering rates are thus considered to be significant.

Recently, the effect biological activity on silicate weathering and mineral growth has been considered (Konhauser and Urrutia, 1999). Bacteria and microorganisms are now known to influence not only weathering, but also clay mineral precipitation. There are seven main biological mechanisms that are generally assumed to influence and increase rates of silicate mineral weathering (Barker et al., 1997): 1) physical disaggregation; 2) soil stabilisation; 3) inorganic acids; 4) organic acids; 5) organic ligands; 6) extracellular polymers; and 7) nutrient absorption. Roots and fungal hyphae physically expose mineral surfaces (Weed et al., 1969) making them more susceptible to chemical weathering processes. Vermiculite has been shown to form from mica via the action of fungi (Weed et al., 1969). Acids produced by the hyphal tips of fungi have been shown to enhance mineral weathering, creating a network of pores in susceptible

(C) 2004 Author(s). This work is licensed under a Creative Commons License. 
minerals (Jongmans et al., 1997). Soil stabilization by plant roots increases water residence time making minerals more prone to chemical weathering (Barker et al., 1997). Production of both organic and inorganic acids as microbial byproducts can affect the weathering process. At extremes of $\mathrm{pH}$, mineral dissolution rates increase by a power law that is dependent on the hydrogen ion activity (Lasaga, 1995). Organic acids in soil, produced as metabolic by-products from microbes and plants, can thus accelerate silicate mineral dissolution. Organic ligands affect weathering by forming complexes with mineral ions at the surface thus enhancing dissolution by weakening bonds (Barker et al., 1997). Oxalic acid is one of many organic acids produced by micro-organisms (Berthelin, 1983) and through its liganding capability rather than $\mathrm{pH}$, has been shown to dissolve four times the quantity of $\mathrm{Al}$ relative to $\mathrm{CO}_{2}$ rich water (Manley and Evans, 1986). Extracellular polymers affect weathering in various ways (Barker et al., 1997). Not only do they bind soil and prevent it drying out, they also act as ligands and nucleation sites for mineral authigenesis (Barker et al., 1997). The anti-dessication qualities of extracellular polymers are particularly important because residence time of water in soil is a primary factor that controls mineral weathering rates. Finally, elements released by weathering processes are utilised as nutrients by microorganisms, enhancing biological activity and stimulating a positive feedback loop. For example, aqueous potassium is often utilised by organisms, a common source of this being the weathering of mica (Weed et al., 1969).

Laboratory experiments have shown that microorganisms can enhance the dissolution rates of minerals (Barker et al., 1997). It is, however, unclear to what extent this effect occurs in the natural environment. Initial work on this issue was undertaken by Konhauser and Urrutia (1999) during which amorphous clay-like minerals were found to be intimately associated with bacterial cell surfaces. This led to the conclusion that bacteria facilitate the growth of authigenic silicate minerals. The release of cations from silicate minerals increases when bacteria are present (Barker et al., 1998). Extensive etching of mineral surfaces has also been repeatedly documented (e.g. Frankel, 1977). This exacerbation of weathering is especially pronounced when essential nutrients, for example phosphorus, are contained within the mineral (Rogers et al., 1998). The mechanisms by which bacteria enhance weathering are still unclear but Vandevivere et al. (1994) found that bacteria significantly enhanced dissolution rates of feldspars even at neutral $\mathrm{pH}$ when compared with abiotic controls. Silica dissolution rates were calculated as $113 \times 10^{-11} \mathrm{~mol} . \mathrm{m}^{-2} \mathrm{~s}^{-1}$ for the bacterial experiments and $0.58 \times 10^{-11} \mathrm{~mol} . \mathrm{m}^{-2} \mathrm{~s}^{-1}$ for the control experiment. This suggests that bacterially-produced organic acids increased reaction rate.

There is therefore a modest amount of information about bacterially-enhanced weathering processes. However, the effect of higher organisms on weathering rates has seldom been addressed. This is somewhat surprising since almost all higher organisms have bacterial gut populations and practically all sedimentary environments contain animals. It seems possible that ingestion and digestion of minerals by higher organisms could produce similar, if not more pronounced effects on weathering rates than microorganisms.

The gut conditions of certain bivalves has been linked to the assimilation, in particular metal uptake and release, from ingested sediment (Griscom et al., 2002). However, specific work on clay minerals and macrobitic ingestion processes is limited. Several workers have documented that earthworms can change the physical properties of soil (Darwin, 1881; Lee, 1985; Suzuki et al., 2003). These changes occur during ingestion and digestion of soil, and are manifested as changes in soil aeration, stability, porosity, grain shape, grain size and water-storage capacity. The geochemical effects of soil ingestion by earthworms has been mentioned (Joshi et al., 1952; Lee, 1985; Basker et al., 1992, 1994) but little has been published on the specific topic of changes in mineralogy or mineral chemistry. For example, Basker et al. $(1992,1994)$ reported that changes in potassium availability occurred in soils ingested by earthworms. Exchangeable potassium content increased significantly in soils populated by earthworms when compared against the same soils devoid of earthworms (Basker et al., 1992). Experiments to assess the effects of digestion by higher organisms on minerals have been attempted (Anderson et al., 1958; Pryor, 1975; Syvitski and Lewis, 1980). However, in these studies thermodynamically stable, low-temperature clay minerals were fed to the organisms, thereby reducing the driving force for dissolution/alteration and also neoformation of minerals. The mineralogical effects reported were varied, but Pryor (1975) reported that chlorite was destroyed and mixed-layer clay minerals were partially destroyed following ingestion of suspended clays by the marine shrimp Callianassa major. The copepod Tigriopus californicus has been shown to alter ingested tremolite and clinochlore to chamosite and montmorillonite to vermiculite (Syvitski and Lewis, 1980).

The study reported herein utilised finely ground, hightemperature non-clay silicate minerals in order to identify any changes that occur during sediment digestion. Our initial experiments were carried out using crushed slate and the common lugworm Arenicola marina (Mcllroy et al., 2003).

\subsection{Worms and sediments}

The guts of all organisms are complex, chemical microenvironments. In particular, the influence of reduced $\mathrm{pH}$, mechanical grinding, enzymes, the chemically-reducing gut environment and gut flora must be considered. The $\mathrm{pH}$, Eh and enzyme activity of various deposit-feeding marine polychaetes has been studied by Ahrens and Lopez (2001). This work demonstrated that most deposit-feeding animals have gut $\mathrm{pH}$ values that are 1-2 orders of magnitude lower than that of ambient seawater ( $\mathrm{pH}$ 8). Low $\mathrm{pH}$ can accelerate 


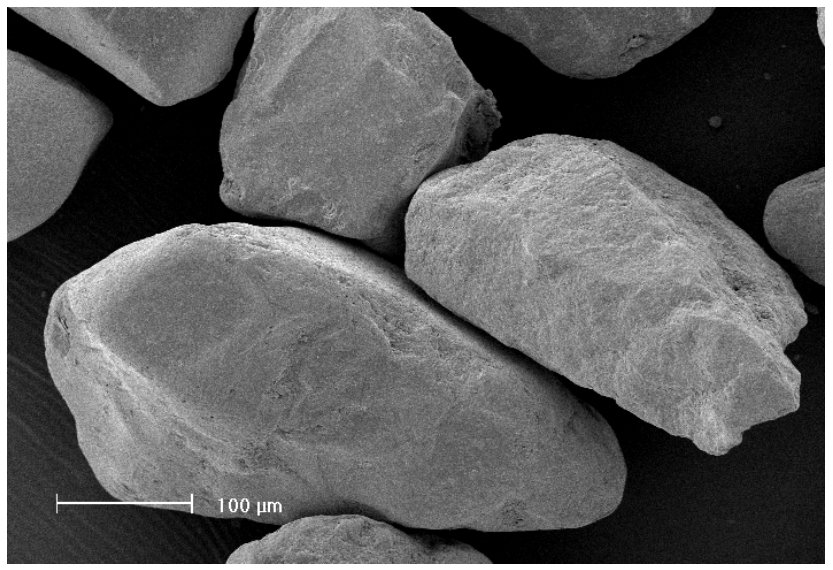

Fig. 1. SEM micrograph of the sand grains fed to the lugworms and earthworms. The sand-size component is clean, clay-free sand.

reactions and increases the absolute solubility of minerals (Lasaga, 1981). The gut of Arenicola marina is as low as 5.4, representing hydrogen ion activity several hundred times greater than in ambient seawater, Kermack (1955). Although most studies have not assessed A. marina specifically, Ahrens and Lopez (2001) used numerous other deposit feeding polychaetes and found their Eh to be slightly reducing. They also detected protease activity as well as the presence of surfactants. Recent work by Plante and Jumars (1992) used microelectrodes to determine gut conditions in deposit feeding organisms and found that anoxic (low Eh) conditions are prevalent and that Eh values decreased from foregut to mid-gut; suggesting than ferrous clay minerals should result rather than ferric clay minerals. However, gut chemistry conditions in macrobiota are by no means constant or similar. Gut $\mathrm{pH}$ for instance can vary from the acidic to near neutral. Terrestrial/freshwater organisms often have a more chemically severe environment than their marine counterparts (Plante et al., 1990). Gut conditions, however, are often different from the ambient and can vary radically between different members of the annelids (Plante et al., 1990; Plante and Jumars, 1992; Chen et al., 2000; Ahrens and Lopez, 2001).

If these hostile micro-environments do indeed accelerate the weathering process, then the expected products of sediment ingestion and digestion should be clay minerals. The origin of clays has previously been considered in sedimentary and diagenetic environments (Worden and Morad, 2003) and this current study offers the possibility of developing a biological link (both palaeobiological and palaeoenvironmental) to clay mineral formation.

If clay minerals can indeed be produced biologically, there are important implications for reservoir geology and the prediction of reservoir quality (McIlroy et al., 2003). Clay coatings on sand grains can both reduce (illite) or preserve (chlorite) porosity and can profoundly affect the economic viability of petroleum reservoirs (Worden and Morad, 2003). A

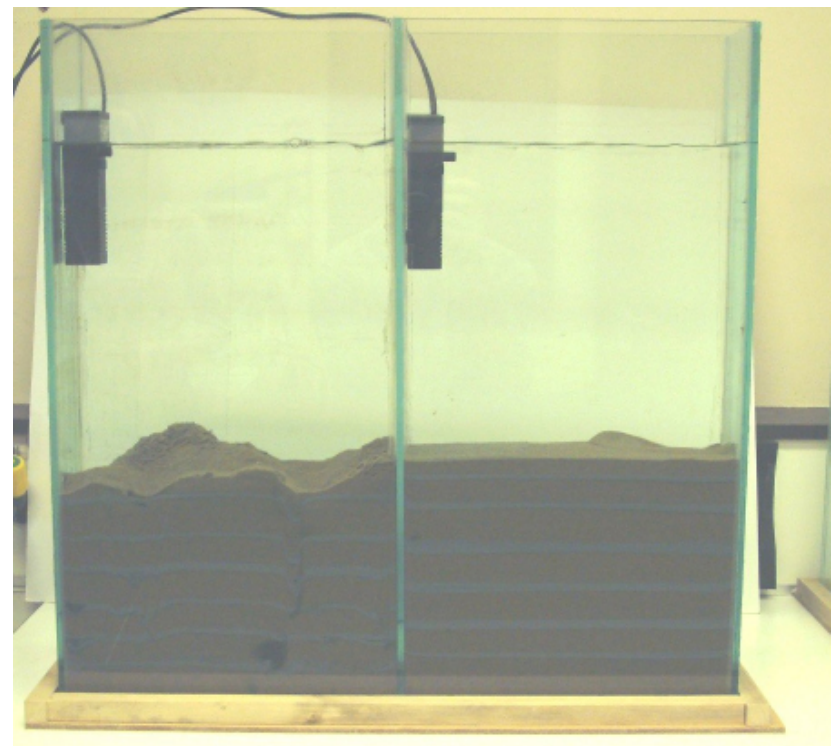

Fig. 2. Photograph of the experimental set-up for the lugworm-slate experiment. Tanks measure $60 \mathrm{~cm}$ in width.

predictable biological origin for these clays or their precursors could put tighter control on prospective areas of good porosity/reservoir potential.

\section{Methods}

\subsection{Experimental methods}

This study required strict experimental protocol. In particular, two issues needed addressing. Firstly, all experiments had a control equivalent that was devoid of worms. Secondly, all experiments and samples collected were treated in exactly the same way in order to facilitate comparison. The experiments were conducted in glass tanks of varying sizes with central partitions that separated the experiment and control tanks. Biologically-active, open-marine seawater collected locally from West Kirby (Merseyside, UK) was added to both sides of the tank along with layered sediment. These layers were alternately composed of wind-blown sand (determined by SEM analysis to be virtually clay free; Fig. 1) and finely crushed Lower Cambrian Welsh slate. The source of sand was chosen because it was local to the lugworms' habitat and because it was texturally and mineralogically mature. This reduces the possibility of any experimental contamination with non-synthetic clay minerals. The slate was chosen because its composition was dominated by high-temperature, highly crystalline chlorite and muscovite (Merriman and Frey, 1999). This assemblage is inherently unstable at surface temperatures and pressures (STP), since it reached metamorphic conditions of approximately $300^{\circ} \mathrm{C}$, thus enhancing the likelihood of reaction and the creation of neoformed clay 


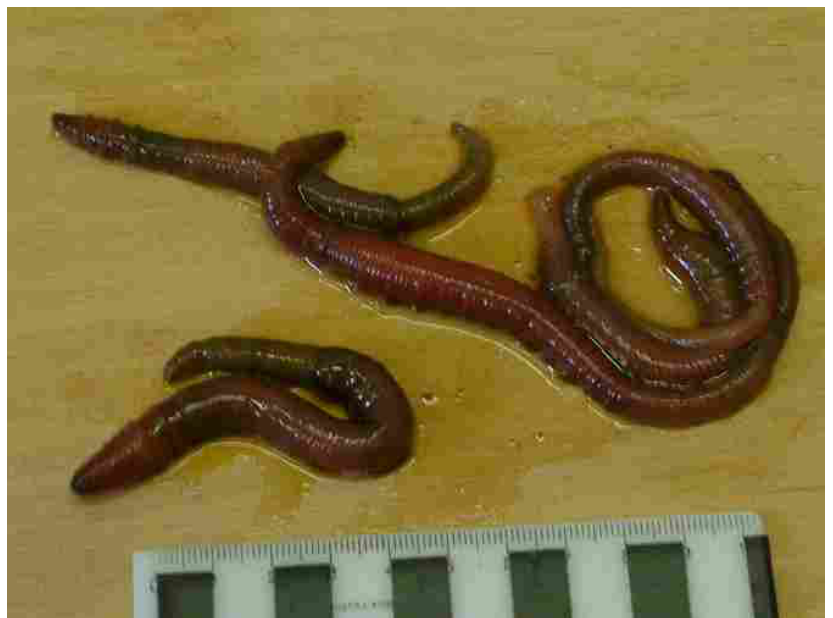

Fig. 3. Photograph of Arenicola marina (common lugworm). Scale bar $10 \mathrm{~cm}$.

minerals. Seven marine polychaetes (the lugworm Arenicola marina), collected from West Kirby, were added to the tank and the water was aerated using a recirculating pump. This experimental set-up is shown in Fig. 2.

Lugworms (Fig. 3) were chosen for the experiments because they are deposit feeders and thus relatively nonselective in their feeding strategy. Their mouth area, an eversible pharynx, is constructed such that selective ingestion does not occur within the size-range of particles that can possibly be ingested (Wells, 1952). This morphology is a by-product of the intensive nature of such a feeding strategy. Lugworms ingest large quantities of sediment in order to gain nutrition from any micro-organisms, meiofauna and labile organic matter in the ingested sediment. Many sediments are low in such foodstuffs, requiring A. marina to process large quantities of sediment. Lugworms cast (excrete) their faeces at the sediment-water interface making sample collection from the experimental tank relatively easy.

Lugworms were collected from sandy sediment at low tide in the Dee Estuary. The most reliable method involved digging a trench in close proximity to lugworm tail shafts to approximately $80 \mathrm{~cm}$ depth, back-slicing into the trench, whilst examining the sediment for any lugworms. The pumping of oxygenated water through the burrow commonly produces an oxidised lining around the burrow shaft that can clearly be differentiated from the reducing, pyritic sands below the redox interface (Fig. 4; Berner, 1980). Before being placed in the experimental side of the tank, the lugworms were starved for at least $48 \mathrm{~h}$ to reduce the risk of introducing contaminant sediment from the Dee Estuary. No lugworms were added to the control side of the tank but the sediment was layered in exactly the same way as the experiment, and used marine water collected from the same locality at the same time as that used in the experimental side of the tank. The resulting bioturbation fabrics were regularly photographed and the casts,

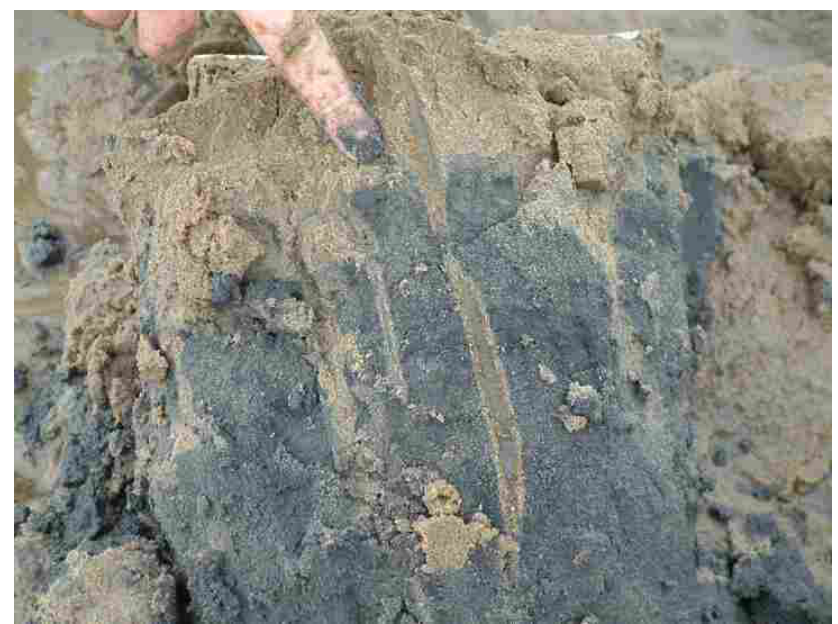

Fig. 4. Photograph of a lugworm burrow cross section. Note the oxidised lining to the burrow in the reduced, pyritic sands. Finger for scale.

which appear on the sediment surface, were collected using a scoop. The lugworm experiment began in October 2002 and is still running at the time of publication.

A second experiment with a different species of worm was set up in a similar manner to the lugworm experiment. This involved an experimental tank, a control tank and starting material of crushed slate. However, instead of lugworms, the soil dwelling oligochaete (the earthworm Lumbricus terrestris) from a local garden were used. The earthworm experiment simulates a non-marine environment since small quantities of fresh water were added to the tank (keeping the sediment moist but not saturated) instead of ample seawater. In contrast to the biologically-active seawater/lugworm experiments, it was necessary in this second case to feed the earthworms since the synthetic environment was sterile. Cabbage was chosen as the source of food since it lacks any mineral content. This experiment is also currently still running.

\subsection{Analytical methods}

After the casts from all of the experiments were collected, they were transferred to small, air-tight containers in preparation for X-ray diffraction (XRD) analysis. The control tank was also sampled periodically and treated with the same experimental and analytical protocol as the faecal casts. The samples were washed and deflocculated by several centrifugation steps. The $<2 \mu \mathrm{m}$ fraction was then separated by centrifugation. A suspension of the $<2 \mu \mathrm{m}$ fraction was pipetted onto a glass slide and dried in an oven. It is important to note that grain size separation was performed on all samples: faecal casts, original material and control material. This precludes the possibility that any changes observed via XRD are an artefact of sample preparation. The slides were weighed before and after the clay fraction was added in 
order to ensure that equal quantities of clay suspension were added to each slide. X-rays have a similar wavelength to the lattice spacing of common rock forming minerals and have been used to characterize crystal structure and mineralogy of earth materials by using X-ray diffraction (XRD) analysis. An XRD analyser includes an X-ray source, the sample and a detector to collect and measure the intensity of the diffracted $\mathrm{X}$-rays. The source and detector are simultaneously rotated about the sample, and both define the same angle $(\theta)$ relative to the sample so the angle between the source and the detector is thus defined as $2 \theta$. Diffraction occurs when X-rays are bounced out of material with a regular series of layers. Each rock-forming mineral has a well-defined set of layers that constitute the crystal lattice. No two minerals have exactly the same crystal structure so that fingerprinting a mineral by its characteristic set of lattice spacings helps to identify its presence. The intensity of the collection of diffraction peaks from a given mineral in a mixture (e.g. rock, soil or sediment) is broadly a function of the proportion of the mineral in the mixture so that peak height represents the quantity of that mineral (Moore and Reynolds, 1997).

Several original crushed rock samples, control samples and faecal cast samples were analysed with a Siemens D500 diffractometer using monochromatic $\mathrm{Cu} \mathrm{K} \alpha$ radiation $(0.15418 \mathrm{~nm})$ operated at $40 \mathrm{kV}$ voltage and $40 \mathrm{~mA}$ current. The detector used was a scintillation counter. A $1 \mathrm{~mm}$ divergent slit, $0.6 \mathrm{~mm}$ detector slit, $1 \mathrm{~mm}$ anti-scatter slit and a graphite monochromator were used. Samples were scanned with a step size of $0.02^{\circ}$ and a count time of $2 \mathrm{~s}$ per step.

Faecal and control samples were continually sampled throughout the course of the experiments. This ensured that a large data set existed for the experiment. Thus if any mineralogical changes were observed in the faecal casts, the large number of collected samples allows a certain amount of replication to be inferred. However, the large-scale experiment itself was not replicated since this would require a large amount of extra resources and time.

\section{Results}

Once introduced to the experimental side of the tank, the lugworms burrowed to a depth of approximately $20 \mathrm{~cm}$ within a matter of minutes. The burrows were J-shaped and mixed the synthetic sand and mud layers to produce a heavily bioturbated fabric. Initial fabric disruption could be documented even after only $2 \mathrm{~h}$ of the lugworms being introduced into the tank. Fabric disruption was less evident in the earthworm tank than in the lugworm tank since these animals do not live in semi-permanent vertical burrows but burrow freely in the matrix. It is important to note that both sides of the tank were treated in exactly the same way. Over the time period of the experiment, control samples were routinely analysed along with faecal cast samples.

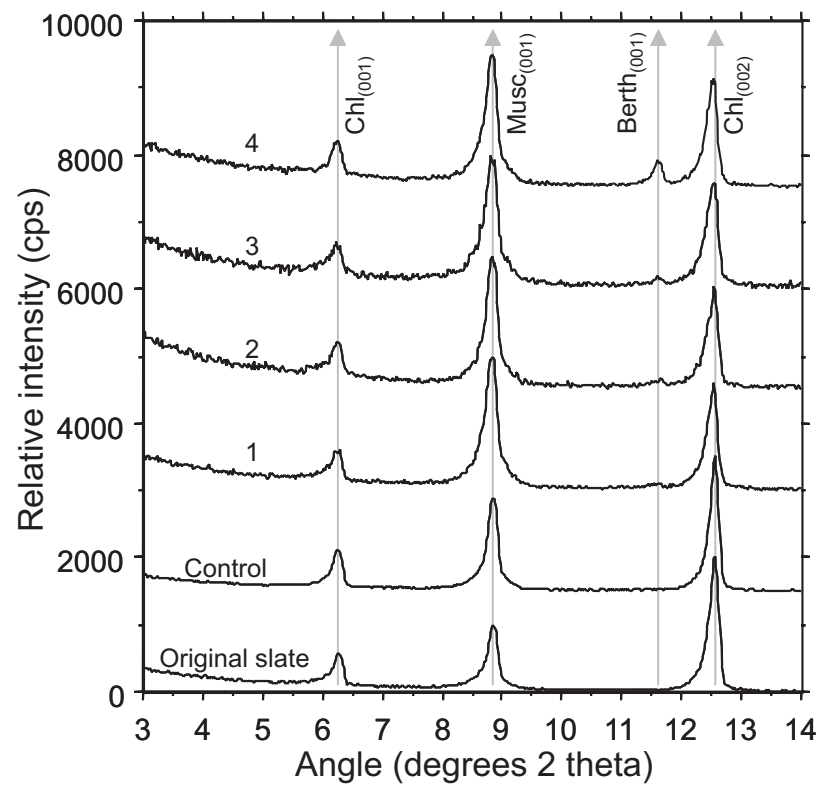

Fig. 5. Data from the lugworm-slate experiment. Original and control are unchanged. However, in faecal casts there is an increase in background noise. Chlorite $_{(002)}$ shows a greater relative degradation when compared against muscovite $(001)$. A new mineral peak occurs in cast samples at $11.7^{\circ} 2 \theta$.

Careful analysis of the diffraction traces showed that: 1) control samples were unchanged when compared with original samples (Fig. 5); and 2) the ratios of mineral maximum intensity peaks heights were changed in the faecal samples relative to the starting material. Although the experiment and control were treated in exactly the same way, the ratio of the height of the chlorite $(002)$ peak to the height of the muscovite (001) peak was significantly lower in the faecal samples in comparison to the original and control samples that had effectively identical chlorite $(002)$ to muscovite $(001)$ peak height ratios.

New, but poorly developed, reflections at $11.7^{\circ} 2 \theta$ appeared in faecal samples (Fig. 5). This represents the neoformation of a mineral not present in either the original or control samples. Detailed analysis of the diffraction traces, particularly at low $2 \theta$ angles (high $d$-spacing), showed small, ill-defined peaks representing the growth of new mineral phases with very high (001) d-spacings (Fig. 6). Other poorly-developed new peaks occurred in the $12.04^{\circ} 2 \theta$ region (Fig. 7).

When the X-ray diffraction traces of the faecal samples are compared to the original and control samples, they appear to have a greater amount of background noise reflecting a general degradation of the highly crystalline starting minerals (Figs. 5 and 6).

In comparison to the original and control samples, there was a distinct broadening of the maximum intensity peaks of the major minerals (muscovite and chlorite) in all faecal 


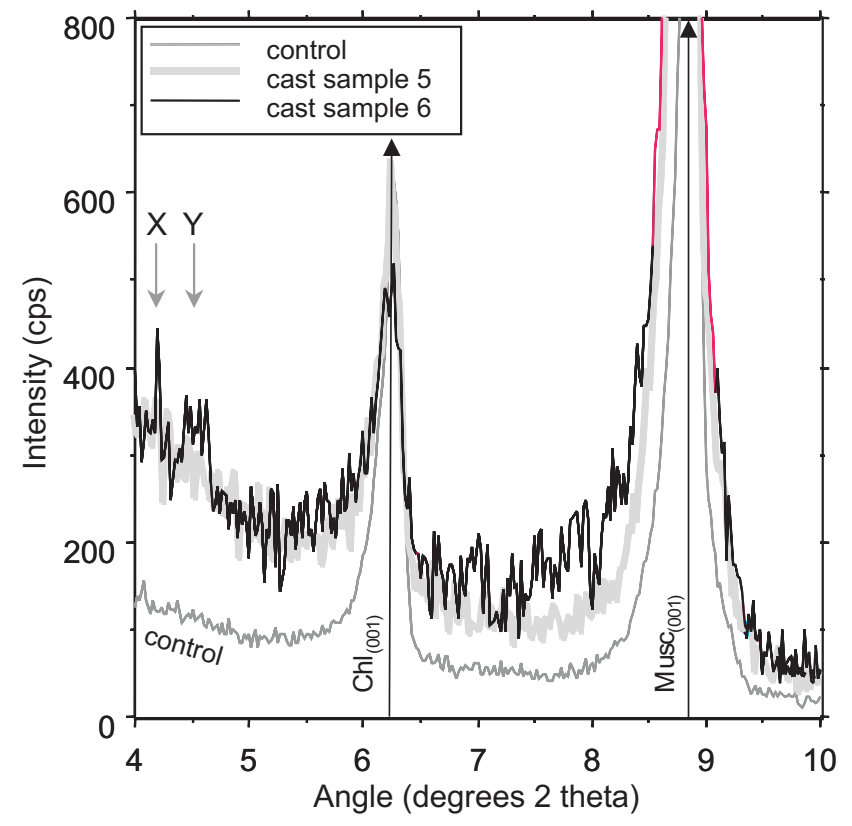

Fig. 6. XRD scan from the lugworm-slate experiment showing increased noise in faecal casts. New peaks appear at very low $2 \theta$ angles. Peaks in faecal samples are broader and have a low angle $2 \theta$ skew when compared with the original material.

samples (Fig. 6). In a reciprocal approach to that employed for determining the change in illite and chlorite crystallinity during progressive metamorphism (e.g. Kisch, 1991; Krumm and Buggisch, 1991; Warr and Rice, 1994), peak widths were measured at one-quarter peak height above background for muscovite and chlorite in order to eliminate the effects of background noise. Primary mineral peak broadening was most evident for the chlorite $(002)$ and muscovite $(001)$ peaks (Figs. 5, 6 and 7). This broadening was manifested mainly as a skew to the low $2 \theta$ angles (higher d-spacing side) of the major peak (Fig. 6). As the peaks become broader they also developed slightly lower peak maximum values (Fig. 8).

Changes in faecal mineralogy also occurred in the earthworm experiment. A $58-63^{\circ} 2 \theta$ scan was conducted in order to differentiate between clay minerals that have similar peak positions in the $2-35^{\circ} 2 \theta$ scan range. XRD analyses in the $58-63^{\circ} 2 \theta$ range for $\mathrm{Cu} \mathrm{K} \alpha$ radiation permit optimum clay mineral identification (Moore and Reynolds, 1997). These scans showed the growth of a new mineral at $60.9^{\circ} 2 \theta$ not present in either original or control samples (Fig. 9).

Many of these mineralogical observations could be improved by detailed observation using other analytical techniques. For example, Transmission Electron Microscopy (TEM) could be capable of determining the precise clay minerals formed by the sediment ingestion process. However, such techniques were considered inappropriate for this study. It can be seen from the XRD traces that the quantities of new mineral produced are small. The amount of extractable clay-

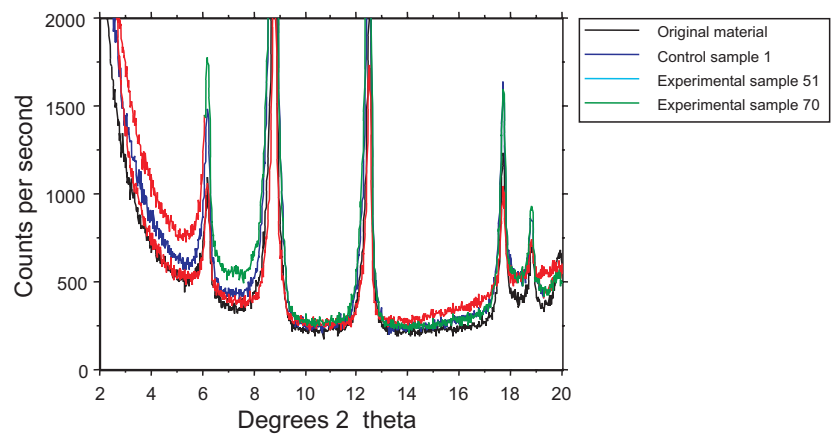

Fig. 7. XRD scan from the lugworm-slate experiment showing a poorly developed peak at $12.04^{\circ} 2 \theta$.

grade material obtained from the faecal samples is very small $(20 \mathrm{mg})$. Of this, perhaps only 5\% represents neoformed minerals. The precise isolation and analysis of this $5 \%$ is thus difficult, and it was considered sufficient to analyse the mineralogy of the samples in a bulk manner as represented by the XRD.

\section{Discussion}

The peak height ratio change seen in the faecal samples is consistent with a change in mineral proportions (Moore and Reynolds, 1997). Since the control and original samples were treated in exactly the same way and because the eversible pharynx of A. marina is not suitable for selective ingestion, changes in chlorite-muscovite maximum intensity peak height ratios cannot be due to experimental artefacts or selective ingestion. The relative decrease in the quantity of chlorite in faecal samples is therefore attributable to sediment ingestion and digestion. The results indicate that these combined processes preferentially remove chlorite from the mineral assemblage.

The relative decrease in the quantity of chlorite in the faecal samples is most likely linked with the growth of the new minerals seen in Figs. 5-7. The new peak at $11.7^{\circ} 2 \theta$ is thus likely to be a product of chlorite decomposition. Berthierine is a $\sim 7 \AA$ clay mineral related to the serpentine group, that has a similar bulk composition to chlorite but primarily contains ferrous, rather than ferric, iron unlike the related $\sim 7 \AA$ "green marine clays" phyllite and odinite (Chamley, 1989). Poorly crystalline berthierine has been reported to have peaks at $11.7^{\circ} 2 \theta$ for $\mathrm{Cu} \mathrm{K} \alpha$ radiation (Odin and Matter, 1981). Since, like other annelids, the guts of $A$. marina are anoxic (e.g. Ahrens and Lopez, 2001), it seems more likely that ferrous berthierine would be a breakdown product of chlorite rather than the ferric clay minerals (for example, phyllite V). Despite work that has suggested that berthierine only grows under tropical conditions (e.g. Odin and Matter, 1981), it has been reported in temperate, high latitude environments (e.g. Scottish sea-lochs; Rohrlich et al., 1969). 


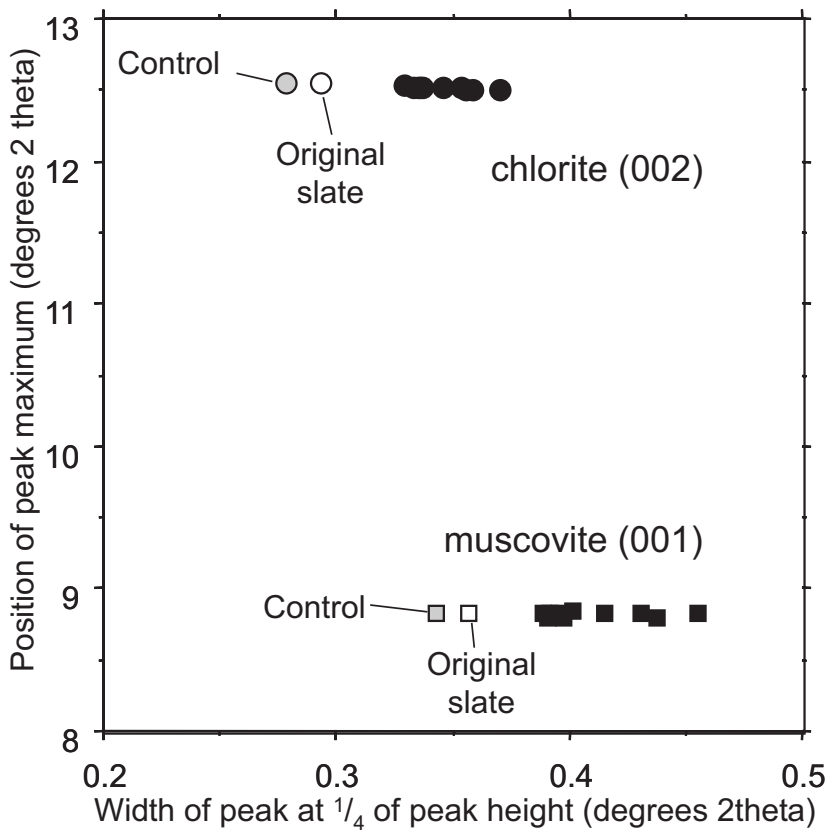

Fig. 8. Worm faecal casts (black) have broader diffraction peaks than original (open) and control (grey) samples. Data shown for chlorite $_{(002)}$ (circles) and muscovite $(001)$ (squares). Data from the lugworm-slate experiment.

The diffraction peaks of faecal samples are uniformly broader than the original and control samples. This represents a degradation of the initial crystal lattices in faecal mineral samples. Well crystalline minerals have tight, narrow peaks consistent with a regular crystal lattice. The faecal samples have thus undergone a decrease in crystallinity. This cannot have been the result of immersion in seawater since control samples exhibited no detectable peak broadening. Sediment ingestion and digestion must therefore have degraded the initial minerals as well as creating a microenvironment suitable for mineral authigenesis.

Peak broadening of chlorite and muscovite in faecal samples showed a tendency to skew towards the low $2 \theta$ side of each peak. This suggests that any new mineral growth happens towards the higher d-spacing region, a characteristic of smectite growth at the expense of muscovite and chlorite. The high degree of noise in all faecal traces in comparison to the original and control samples also reflects mineral degradation in the gut of $A$. marina. It most likely suggests the partial and inchoate growth of a whole range of new, poorly crystalline, minerals. Much of this mineral growth is likely to have happened at the expense of chlorite (Fig. 5), although muscovite may also have undergone alteration.

These mineralogical changes do not appear to be limited to lugworms. The earthworm experiments have showed new mineral growth, specifically in the $60.9^{\circ} 2 \theta$ region. There are few minerals with peaks in this range. Possible candidates for this are the tri-octahedral smectite saponite, nontronite or

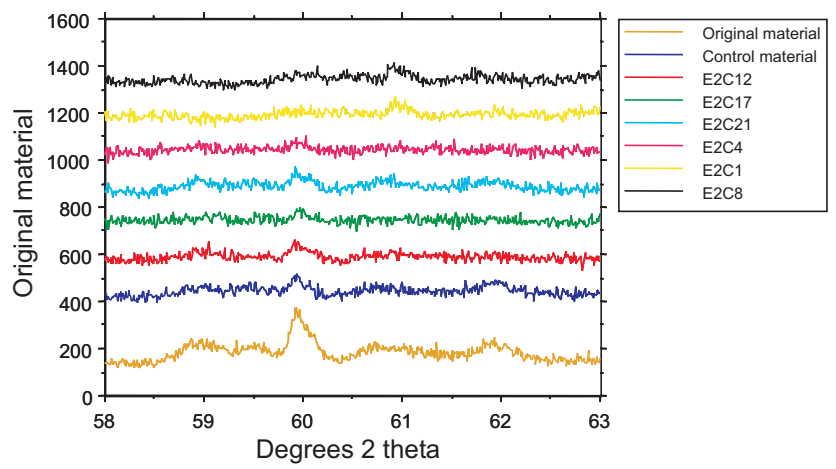

Fig. 9. New mineral peaks in the faecal samples at $60.9^{\circ} 2 \theta$ in the earthworm-slate experiment.

berthierine. The balance of probabilities suggests that primary chlorite has broken down to berthierine during earthworm ingestion as it did for lugworm ingestion.

These results thus seem to show that sediment ingestion and digestion by both the lugworm, A. marina, and the earthworm, L. terrestris, creates a hostile microenvironment, degrades crystal lattices and induces mineral authigenesis. The production of newly formed clay minerals in faecal casts suggests that digestion can accelerate the weathering process.

There are many factors that could cause the observed mineralogical effects. The experiment utilised minerals that would naturally decay over geological timescales, but would not decay under abiotic conditions on the timescale of these experiments. Inorganic weathering reactions are sensitive to $\mathrm{pH}$, and occur faster at low $\mathrm{pH}$ than at neutral $\mathrm{pH}$. The $\mathrm{pH}$ range of the gut of $A$. marina is from 5.4 to 7.0 (Kermack, $1955)$, which is clearly very different from the $\mathrm{pH}$ of ambient seawater ( $\mathrm{pH} 8)$. The guts of many other deposit feeding polychaetes have much lower $\mathrm{pH}$ than $A$. marina (Ahrens and Lopez, 2001). Gut pH is, however, a parameter that displays great variability between different members of the annelid group. For example, some earthworms can have been reported to have a near-neutral gut pH (Horn et al., 2003)

As well as having a reaction-inducing low $\mathrm{pH}$, the guts of $A$. marina are also extremely biologically active environments that are rich in bacteria and enzymes. The link between bacteria and clay mineral precipitation has already been made (Konhauser and Urrutia, 1999). Enzymes are known biological catalysts that tend to work on even shorter timescales than bacteria. The role of enzymes awaits investigation by mineralogists.

Of subordinate importance are other factors such as the powerful mechanical grinding action of guts caused by the peristaltic movements used to move food along the gut. The Eh of deposit feeding polychaetes is also reducing (Ahrens and Lopez, 2001) although this might more control the oxidation state of $\mathrm{Fe}$ in neoformed clay minerals rather than the fundamental rate of mineral alteration. 
It is likely that the precise causative mechanism for the observed changes will be hard to identify and characterise. The complexity of natural, biological systems will most likely result in no one single factor being responsible for the observed changes. Rather, a combination of low $\mathrm{pH}$ and the extremely active microbiological environment in the guts of macrobiota result in the degradation and neoformation of silicate minerals. Any such hypotheses would be hard to test in the laboratory. Lugworms devoid of gut micro-organisms would be very difficult to obtain/produce. Similarly, a pure strain of lugworm gut bacteria would be hard to procure and culture.

\section{Conclusions and interpretations}

These experiments have shown that macrobiota are capable of degrading minerals and creating a host environment suitable for clay mineral authigenesis. In essence, the annelids used in these experiments have accelerated the process of weathering. These effects have been noted in microbiota for several years, but have never before been adequately demonstrated to occur in macrobiota.

The combined processes of sediment ingestion and digestion have, over the course of these experiments, degraded the initial minerals and produced new clay mineral products. The clays produced in these sand rich sediments are likely to be metastable and upon burial diagenesis, act as precursors to burial diagenetic clay mineral cements. Notably, the diagenetic minerals expected to grow upon burial are those clays highly detrimental to (pore-filling illite) and also advantageous to (grain-coating chlorite) reservoir quality. Previous models (Odin and Sen Gupta, 1988) that invoked physical sedimentary, inorganic geochemical processes or facies architecture as the dominant factors controlling the formation and distribution of these significant clay minerals may thus be deficient.

The reactions observed in these experiments appear to be generic weathering reactions that have taken place on a much faster timescale than is normally associated with geological processes. Models that consider inorganic rates of weathering and mineral authigenesis may thus significantly overestimate the time required.

It would thus seem to be appropriate to consider weathering rates as highly variable; from the biologically-active warm tropical environments to biologically-restricted cold or deep environments. It is important to note here that sediment ingestion is not restricted to deposit feeding polychaetes. Some organisms, such as lugworms, do it actively, whereas other organisms ingest sediment passively as an inevitable consequence of other feeding strategies. Mussels and shrimps, for example, filter-feed very fine organic matter and ingest suspended clay minerals as a consequence of an intensive feeing strategy. Vertebrate organisms also ingest sediment in order to facilitate digestive processes. Thus these mineralogical effects are not simply restricted to bioturbated, annelid-rich environments.

These experiments have also made no attempt to quantity the sediment recycling that goes on in the natural environment. Not only does sediment in the shallow marine zone pass through lugworms repeatedly, but it also passes through a multitude of other animals, each with specific gut conditions. Future work on clay mineral occurrence should thus take into account the entire coprophagic cycle.

Acknowledgements. Financial support from Statoil and technical support from S. Blackburn, S. Crawley, J. Kavanagh and K. Veltkamp are recognised with thanks. Statoil are thanked for funding this research and for permission to publish. The authors would also like to thank the two anonymous reviewers for their constructive comments and suggestions.

Edited by: J. Middelburg

\section{References}

Ahrens, M. J. and Lopez, G. R.: In vivo characterization of the gut chemistry of small deposit-feeding polychaetes, In: OrganismsSediment Interactions, edited by: Aller, J. Y., Woodin, S. A., and Aller, R. C., University of South Carolina Press, Columbia, 349368, 2001.

Anderson, A. E., Jonas, E. C., and Odum, H. T.: Alteration of clay minerals by digestive processes of marine organisms, Science, 127, 190-191, 1958.

Barker, W. W., Welch, S. A., and Banfield, J. F.: Biogeochemical weathering of silicate minerals, In: Geomicrobiology: Interactions Between Microbes and Minerals, Reviews in Mineralogy, 35, edited by: Banfield, J. F. and Nealson, K. H., Mineralogical Society of America, Washington DC, 391-428, 1997.

Barker, W. W., Welch, S. A., Chu, S., and Banfield, J. F.: Experimental observations of the effects of bacteria on aluminosilicate weathering, Am. Mineral., 83, 1551-1563, 1998.

Basker, A., Macgregor, A. N., and Kirkman, J. H.: Influence of soil ingestion by earthworms on the availability of potassium in soil: an incubation experiment, Biol. Fert. S., 14, 300-303, 1992.

Basker, A., Kirkman, J. H., and Macgregor, A. N.: Changes in potassium availability and other soil properties due to soil ingestion by earthworms, Biol. Fert. S., 17, 154-158, 1994.

Berner, R. A.: Early diagenesis: a theoretical approach: Princeton University Press, Princeton, 1980.

Berthelin, J.: Microbial weathering processes, In: Microbial Geochemistry, edited by: Krumbein, W. E., Blackwell Scientific Publications, Oxford UK, 223-262, 1983.

Chamley, H.: Clay Sedimentology, Springer, Berlin, 1989.

Chen, Z., Mayer, L. M., Quétel, C., Donard, O. F. X., Self, R. F. L., Jumars, P. A., and Weston, D. P.: High concentrations of complexed metals in the guts of deposit feeders, Limnol. Oceanogr., 45, 1358-1367, 2000.

Darwin, C.: The formation of vegetable mould, through the action of worms, John Murray, London, 1881.

Drever, J. I.: The Geochemistry of Natural waters, Prentice-Hall, Englewood Cliffs, New Jersey, 1988. 
Drever, J. I. and Clow, D. W.: Weathering rates in catchments, In: Chemical Weathering rates of Silicate Minerals, Reviews in Mineralogy 31, edited by White, A. F. and Brantley, S. L., Mineralogical Society of America, Washington DC, 463-483, 1995.

Frankel, L.: Microorgansim induced weathering of biotite and hornblende grains in estuarine sands, J. Sed. Pet., 47, 849-854, 1977.

Griscom, S. B., Fisher, N. S., Aller, R. C. and Lee, B. G.: Effects of gut chemistry in marine bivalves on the assimilation of metals from ingested sediment particles, J. Marine Res., 60, 101-120, 2002.

Horn, M. A., Schramm, A., and Drake, H. L.: The earthworm gut: an ideal habitat for ingested $\mathrm{N}_{2} \mathrm{O}$-producing microorganisms, Appl. Envir., 69, 1662-1669, 2003.

Jongmans, A. G., van Breemen, N., Lundström, U., van Hees, P. A. W., Finlay, R. D., Srinivasan, M., Unestam, T., Giesler, R., Melkerud, P. A., and Olsson, M.: Rock-eating fungi, Nature, 389, 682-683, 1997.

Joshi, N. V. and Kelkar, B. V.: The role of earthworms in soil fertility, I. J. Agr. Sci., 22, 189-196, 1952.

Kermack, D. M.: The anatomy and physiology of the gut of the polychaete Arenicola marina (L.), Proceedings of the Zoological Society of London, 125, 347-381, 1955.

Kisch, H. J.: Illite crystallinity: recommendations on sample preparation, X-ray diffraction settings, and interlaboratory samples, J. Metamorph., 9, 665-670, 1991.

Konhauser, K. O. and Urrutia, M. M.: Bacterial clay authigenesis: a common biogeochemical process, Chem. Geol., 161, 399-413, 1999.

Krumm, S. and Buggisch, W.: Sample preparation effects on illite crystallinity measurement: grain-size gradation and particle orientation, J. Metamorph., 9, 671-677, 1991.

Lasaga, A. C.: Rate laws of chemical reactions, In: Kinetics of Geochemical Processes, Reviews in Mineralogy, vol. 8, edited by Lasaga, A. C. and Kirkpatrick, R. J., Mineralogical Society of America, Michigan, 1-67, 1981.

Lee, K. E.: Earthworms, their ecology and relationships with soils and land use, Academic Press, Sydney, 1985.

Manley, E. P. and Evans, L. J.: Dissolution of feldspars by lowmolecular-weight aliphatic and aromatic acids, Soil Sci., 141, 106-112, 1986.

McIlroy, D., Worden, R. H., and Needham, S. J.: Faeces, clay minerals and reservoir potential, J. Geol. Soc., 160, 489-493, 2003.

Merriman, R. J. and Frey, M.: Patterns of very low-grade metamorphism in metapelite rocks, In: Low Grade Metamorphism, edited by: Frey, M. and Robinson, D., Blackwell, Oxford, 61107, 1999.

Moore, D. M. and Reynolds Jr., R. C.: X-ray Diffraction and the Identification and Analysis of Clay Minerals, 2nd edn., Oxford University Press, New York, 1997.
Odin, G. S. and Matter, A.: De glauconiarum origine, Sedimentology, 28, 611-641, 1981.

Odin, G. S. and Sen Gupta, B. K.: Geological significance of the verdine facies, In: Green Marine Clays, Developments in Sedimentology 45, edited by: Odin, G. S., Elsevier, Amsterdam, 1988.

Plante, C. and Jumars, P.: The microbial environment of marine deposit-feeder guts characterized via microelectrodes, Microb. Ecol., 23, 257-277, 1992.

Plante, C. J., Jumars, P. A., and Baross, J. A.: Digestive associations between marine detritivores and bacteria, Ann. Rev. Ecol. Syst., 21, 93-127, 1990.

Pryor, W. A.: Biogenic sedimentation and alteration of argillaceous sediments in shallow marine environments, Geol. S. Am. B., 86, 1224-1254, 1975.

Rogers, J. R., Bennett, P. C., and Choi, W. J.: Feldspars as a source of nutrients for microorganisms, Am. Mineral., 83, 1532-1540, 1998.

Rohrlich, V., Price, N. B., and Calvert, S. E.: Chamosite in the recent sediments of Loch Etive, Scotland, J. Sed. Pet., 39, 624 $631,1969$.

Suzuki, Y., Matsubara, T., and Hoshino, M.: Breakdown of mineral grains by earthworms and beetle larvae, Geoderma, 112, 131$142,2003$.

Sverdrup, H. and Warfvinge, P.: Estimating field weathering rates using laboratory kinetics, In: Chemical Weathering Rates of Silicate Minerals, Reviews in Mineralogy 31, edited by: White, A. F. and Brantley, S. L., Mineralogical Society of America, Washington DC, 485-541, 1995.

Syvitski, J. P. M. and Lewis, A. G.: Sediment ingestion by Tigriopus californicus and other zooplankton: mineral transformation and sedimentological considerations, J. Sed. Pet., 50, 869-880, 1980.

Vandevivere, P., Welch, S. A., Ullman, W. J, and Kirchman, D. L.: Enhanced dissolution of silicate minerals by bacteria at nearneutral pH, Microb. Ecol., 27, 241-251, 1994.

Warr, L. N. and Rice, A. H. N.: Interlaboratory standardization and calibration of clay mineral crystallinity and crystallite size data, J. Metamorph., 12, 141-152, 1994.

Weed, S. B., Davey, C. B., and Cook, M. G.: Weathering of mica by fungi, Soil Sci. So. Proceedings, 33, 702-706, 1969.

Wells, G. P.: The proboscis apparatus of Arenicola, J. Marine Bi., 31, 1-28, 1952.

Worden, R. H. and Morad, S.: Clay minerals in sandstones: controls on formation, distribution and evolution, In: Clay Mineral Cements in Sandstones, International Association of Sedimentologists Special Publication 34, edited by: Worden, R. H. and Morad, S., Blackwell Publishing, Oxford, 3-41, 2003. 